\title{
Biochemical, histological and histochemical changes in Aristichthys nobilis Rich. liver exposed to thiamethoxam
}

\section{S. STOYANOVA ${ }^{1}$ \\ V. YANCHEVA ${ }^{1, *}$ \\ I. ILIEV ${ }^{2}$ \\ T. VASILEVA 2 \\ V. BIVOLARSKI ${ }^{2}$ \\ I. VELCHEVA ${ }^{1}$ \\ E. GEORGIEVA ${ }^{3}$}

${ }^{1}$ Department of Ecology and Environmental Conservation, Faculty of Biology, Plovdiv University, Plovdiv, 4000, Bulgaria

${ }^{2}$ Department of Biochemistry and Microbiology, Faculty of Biology, Plovdiv University, Plovdiv, 4000, Bulgaria

${ }^{3}$ Department of Developmental Biology, Faculty of Biology, Plovdiv University, Plovdiv, 4000, Bulgaria

\section{*Correspondence:}

Vesela Yancheva

E-mail: veselayancheva@yahoo.com

Key words: Insecticide, Thiamethoxam, Fish Liver, Enzymatic activity, Histological alterations
Received October 23, 2014

Revised February 22, 2016.

Accepted March 03, 2016.

\section{Abstract}

Background and purpose: The aim of the present study was to investigate the effects of the insecticide thiamethoxam on some biochemical, histological and histochemical parameters of bighead carp liver (Aristichthys nobilis), which is an economically important fish species for aquaculture.

Materials and methods: Different increasing concentrations of $6.6 \mathrm{mg}^{-1}, 10 \mathrm{mg}^{-1}$ and $20 \mathrm{mg}^{-1}$ of the test chemical under laboratory conditions were tested for their toxicity on fish for $96 \mathrm{~h}$. The hepatic activity of the enzymes lactate dehydrogenase ( $L D H)$, aspartate aminotransferase (ASAT) and alanine aminotransferase (ALAT) were measured. In addition, the hepatic histological structure was observed for alterations, as well as the lipid content was observed by histochemical staining.

Results: It was determined that the enzymatic activity of the exposed fish was increased compared to the control group $(p<0.05)$. Furthermore, the enzymatic activity was increased proportionally to the increasing thiamethoxam concentrations. The histological lesions, which were observed in the liver parenchyma, were degenerative and necrotic. The degenerative alterations were as follows: granular, balloon and fatty degeneration. The necrotic alterations in the fish liver were associated with presence of karyopyknosis, karyorrehsis and karyolysis, respectively. The histological alterations in the liver blood vessels were hyperemia and lymphocyte proliferation. Along with the established histological changes in the liver parenchyma, we found presence of fatty degeneration in the hepatocytes using Sudan III staining on cryostat sections.

Conclusions: Our study shows that there is a relation between the concentration of the insecticide and biochemical changes, as well the severity of expression of the histological and histochemical alterations in the bighead carp liver. Overall, such experiments could be successfully applied in research and monitoring programs to study the effects of pesticides on fish.

\section{INTRODUCTION}

The common use of insecticides in public health and agricultural 1 schedules has caused severe environmental pollution and potential health hazards including different acute and chronic cases of animal poisonings $(1,2)$.

Neonicotinoids are the newest class of insecticides to be developed and represent the only major new class of insecticides in the past three 
decades. They differ from their natural analogues with high persistence in the environment and more pronounced toxic effects (3).

The contamination of water by insecticides is mainly due to intensive agriculture combined with surface runoff and subsurface drainage, usually within a few weeks after application (4). The continuous presence of insecticides is the consequence of their use (timing, rate, frequency) and the rainfall during the application period $(5,6)$. Several studies reported that some surface waters and surrounding environments were contaminated with different insecticides $(7,8)$.

The fish are particularly sensitive to pollution. They can be exposed to a wide range of toxic substances, including insecticides during their life cycle. In fish, different insecticides can be absorbed through the gills, skin or alimentary ducts, so that they can diffuse into their organs and fat tissues and significantly affect their fundamental physiological and biochemical processes $(9,10)$.

The liver plays an important role in several vital functions of basic metabolism and it is also the major organ of accumulation, biotransformation and excretion of contaminants in fish, including degradation and bioinactivation of pesticides (11-13). Thus, the biochemical parameters in fish liver are sensitive for detecting potential adverse effects and relatively early events of pollutant damage (14). It is important to know how the activity of liver enzymes lactate dehydrogenase (LDH), aspartate aminotransferase (ASAT) and alanine aminotransferase (ALAT) change. They are indicators for normal liver function and hence, they can be also used as biomarkers for tissue damage. Moreover, histopathology provides information on the effects of irritants in various organs (15) and structural damages from the effects of pollutants on liver metabolism have been supported by the results of histopathological studies $(16,17)$. Therefore, the assessment of biochemical and histological changes in the fish liver has become an important tool for evaluation the environmental pollution in experimental conditions $(18,19)$.

Bighead carp is a common freshwater fish species used in recreational fishing. It is also used as a food source through some European countries, including in Bulgaria. However, data from studies carried out on the effects of thiamethoxam on the liver of this particular cyprinid fish are relatively limited.

Therefore, the main goal of the present study is to investigate the effects of thiamethoxam on 1) hepatic activities of lactate dehydrogenase (LDH), aspartate (ASAT) and alanine (ALAT) aminotransferases; 2) histological structure, and 3) histochemical structure of bighead carp liver exposed to thiamethoxam under laboratory exposure.

\section{EXPERIMENTAL PROCEDURES}

\section{Chemicals and experimental setup}

Thiamethoxam is the only active substance of the product for plant protection „Actara 25 WG”. It is a second generation neonicotinoid insecticide, which belongs to the subclass of thianicotinyl, has unique chemical properties and provides excellent, fast-acting and longlasting elimination of a broad range of foliar and soil pests (20).

Forty healthy bighead carps were obtained from the Institute of Fisheries and Aquaculture in Plovdiv, Bulgaria where fish are reared under strict and controlled conditions. They were of the same size-group (mean length $18.65 \mathrm{~cm} \pm 1.33$; mean body mass $53.5 \mathrm{~g} \pm 6.3$ ) with no external pathological abnormalities. After transportation the fish were moved in tanks with chlorine-free tap water (by evaporation) to acclimatize for a week. After acclimatization the fish were divided into four groups $(\mathrm{n}=10)$ in $100 \mathrm{l}$ tanks. They were not fed $48 \mathrm{~h}$ prior to the experiment.

There is no data regarding the $\mathrm{LC}_{50}$ for fish for thiamethoxam. Therefore, three groups of fish were exposed to the insecticide for $96 \mathrm{~h}$ (acute exposure) at concentration of $6.6 \mathrm{mg} \mathrm{l}^{-1}, 10 \mathrm{mg} \mathrm{l}^{-1}$ and $20 \mathrm{mg} \mathrm{l}^{-1}$, representing $30,20,10$ times dilution of the stock solution, prepared according to the instructions of the manufacturer. The fourth fish group served as a control with no added pesticide.

All tanks had a permanent aeration with air pumps and the water was kept oxygen saturated. During the entire duration of the experiment the fish were maintained under a natural light/dark cycle (12:12). The physicochemical characteristics of the water such as: $\mathrm{pH}$, temperature, dissolved oxygen, oxygen saturation and conductivity were measured once per day according to a standard procedure (21). They were as follows: $\mathrm{pH}-$ $8.2 \pm 0.5$; temperature $-20.21^{\circ} \mathrm{C} \pm 1.5$; dissolved oxygen $-9.3 \mathrm{mg} \mathrm{l}^{-1} \pm 0.5$; oxygen saturation $-103.43 \% \pm 0.5$ and conductivity $-320 \mu \mathrm{cm}^{-1} \pm 2.5$.

The fish dissection was performed according to the international standard procedures given in the EMERGE Protocol (22), but divided in two pieces for three different analyses. The experiment was performed in accordance with national and international guidelines of the European parliament and the Council on the protection of animals used for scientific purposes (23).

\section{Biochemical analysis}

The biochemical analysis was conducted at the laboratory of the Department Biochemistry and Microbiology, Plovdiv University. The livers were rapidly thawed on ice and manually homogenized, using a Potter Elvehjem homogenizer fitted with a Teflon pestle in chilled phosphate 
buffer ( $50 \mathrm{mM}, 300 \mathrm{mM} \mathrm{NaCl}, \mathrm{pH}=7.4)$. The homogenates was subjected to centrifugation at $9000 \mathrm{rpm}$ for 15 min in a cooling centrifuge (MPW $351 \mathrm{R}$ ) at $4^{\circ} \mathrm{C}$. The supernatant fractions were aliquoted, transferred in new eppendorf tubes and stored at $-80^{\circ} \mathrm{C}$ for further enzyme assays. All biochemical assays were measured spectrophotometrically (Beckman Coulter Spectrophotometer DU $800)$ at $25^{\circ} \mathrm{C}$. The chemicals used in this study were purchased from Sigma Chemical Co. and were of analytical grade.

Lactate dehydrogenase (LDH, E.C. 1.1.1.27) activity was assayed according to the method of Vassault (24). Aspartate aminotransferase (ASAT, E.C. 2.6.1.1) and alanine aminotransferase (ALAT, E.C. 2.6.1.2) activities were determined by the method of Reitman and Frankel (25) as described by IFCC (26) using commercially available kits.

The protein levels were measured by the Bradford (27) method with Coomassie Brilliant Blue G-250 using bovine serum albumin as standard. The absorbance of samples was detected at $595 \mathrm{~nm}$ and expressed as milligram protein per milliliter homogenate.

One unit of LDH, ASAT and ALAT is defined as the amount of the enzyme that consumes $1 \mathrm{~mol} \mathrm{l}^{-1}$ of substrate or generates $1 \mathrm{~mol} \mathrm{l}^{-1}$ of product per min. The activity was expressed in international units per milligram of protein.

\section{Histological analysis}

The histological analysis was carried out at the laboratory of the Department of Developmental Biology, Plovdiv University. The liver samples were placed in vials with $10 \%$ neutrally buffered formaldehyde solution $(\mathrm{pH}=7)$ for $12 \mathrm{~h}$ and a routine alcohol-xylene processing followed. They were rinsed in tap water, dehydrated in a graded series of ethanol concentrations, cleared in xylene, embedded in paraffin wax with melting point of $54-56^{\circ} \mathrm{C}$, sectioned to a thickness of 5-7 $\mu \mathrm{m}$ using a semi-automated rotary microtome (Leica RM 2245) and mounted on sterilized glass slides. The sections were then deparaffinised, stained with hematoxylin and eosin (H\&E) for histological examinations and prepared for light microscopy analysis (28). The histological changes in the liver were observed and photographed by using a light microscope (Nikon, Japan) mounted with a digital camera.

Liver histology of all specimens, including the control fish livers were appraised individually and semi-quantitatively by using the grading system of Mishra and Mohanty (29). Each grade represents specific histological characteristics and is categorized as follows: $(-)$ - no histological alterations; $(+/-)$ - mild histological alterations; $(+)$ - moderate histological alterations; $(++)$ - severe histological alterations; $(+++)$ - and very severe histological alterations in the hepatic architecture.

\section{Histochemical analysis}

The histochemical analysis was conducted at the laboratory of the Department of Anatomy, Histology and Embryology, Medical University in Plovdiv. Multiple carp liver sections $(6 \mu \mathrm{m})$ of each fish were prepared according to a standard methodology using a cryostat (Leica, Jung Frigocut $2800 \mathrm{~N}$ ). The samples were stained by the Sudan III method according to Daddy (30) as described by Pearse (31).

The liver histochemical alterations from the treated with thiamethoxam fish, as well as the control fish livers were appraised individually and semi-quantitatively by using the grading system described by Mishra and Mohanty (29). The positive Sudan III - reaction was presented in purple-magenta staining in the hepatic cytoplasm. The evaluation of the observed changes was carried out and presented as an average value. Similarly to the histological analysis, each grade represents specific histochemical characteristics and is categorized as follows: (-) - negative reaction of histochemical staining; $(+/-)$ - very weak positive reaction of histochemical staining; $(+)-$ weak positive reaction of histochemical staining; $(++)$ moderate positive reaction of histochemical staining; $(+++)$ - strong positive reaction of histochemical staining in the hepatocytes.

\section{Statistical analysis}

The activity of the hepatic enzymes of all 10 specimens from all test concentrations thiamethoxam was expressed as mean $\pm S D$. Descriptive statistics was performed and software packet STATISTICA (version 7.0 for Windows, StatSoft, 2004) was used. The differences between the individual variables were tested for significance using the Student's t-test $(p<0.05)$ and one-way analysis of variance (ANOVA).

\section{RESULTS AND DISCUSSION}

\section{Enzymatic responses}

Lactate dehydrogenase (LDH) is an enzyme found in almost all body tissues, such as heart, kidneys, liver, skeletal muscle, brain, erythrocyte and gills (32). LDH measurement is used to detect tissue disorders and as an aid in the diagnosis of tissue damage, and it also takes part in the anaerobic pathway of carbohydrate metabolism (33). Aspartate aminotransferase (ASAT) and alanine aminotransferase (ALAT) are liver specific enzymes, participating in the amino acids metabolism. They are sensitive indicators for hepatotoxicity and histophathalogic changes, and can be assessed within a shorter time (34).

The enzymatic activity of LDH, ASAT and ALAT (Table 1) was increased at all thiamethoxam concentrations compared to the control group $(p<0.05)$. Exposure of the fish to thiamethoxam for 96 hours increased LDH 
Table 1. Hepatic activities of LDH, ASAT and ALAT in bighead carp (average $\pm S D$ ) at all tested thiamethoxam concentrations, including enzymatic responses in control fish.

\begin{tabular}{|lccc|}
\hline \multirow{2}{*}{$\begin{array}{l}\text { Thiamethoxam } \\
\text { concentration }\end{array}$} & \multicolumn{3}{c}{ Activities of hepatic enzymes, $\mathrm{U} \mathrm{mg} \mathrm{l}^{-1}$ protein } \\
\cline { 2 - 4 } & $\mathrm{LDH}$ & ASAT & ALAT \\
\hline Control group & $6.16 \pm 0.04$ & $0.53 \pm 0.03$ & $0.3 \pm 0.4$ \\
$6.6 \mathrm{mg} \mathrm{l}^{-1}$ & $12.18 \pm 0.048^{*}$ & $0.84 \pm 0.02^{*}$ & $0.87 \pm 0.04^{*}$ \\
$10 \mathrm{mg} \mathrm{l}^{-1}$ & $12.25 \pm 0.03^{*}$ & $0.89 \pm 0.03^{*}$ & $0.91 \pm 0.02^{*}$ \\
$20 \mathrm{mg} \mathrm{l}^{-1}$ & $14.21 \pm 0.04^{*}$ & $0.91 \pm 0.04^{*}$ & $0.94 \pm 0.02^{*}$ \\
\hline
\end{tabular}

activity in all test fish groups compared to the control. LDH activity of the test group exposed to $6.6 \mathrm{mg} \mathrm{l}^{-1}$ thiamethoxam was increased with $97.7 \%$ (1.98 times) compared to the control group. We also found that the LDH activity increased with $98.8 \%$ (1.99 times) and $130.6 \%$ (2.3 times) at $10 \mathrm{mg} \mathrm{l}^{-1}$ and $20 \mathrm{mg} \mathrm{l}^{-1}$ thiamethoxam concentrations when compared to the control group, respectively. The statistical analysis showed a significant difference $(p<0.05)$ among the enzyme responses at all test concentrations compared to the control fish group. In addition, the LDH activity in the fish groups increased in the following descending order $6.6 \mathrm{mg} \mathrm{l}^{-1}<$ $10 \mathrm{mgl}^{-1}<20 \mathrm{mgl}^{-1}$ thiamethoxam, respectively $(p<0.05)$.

Das and Mukherjee (35) reported increased LDH activity in the liver of Indian major carp, Labeo rohita exposed to cypermethrin. Similarly to us, Oruç and Üner (36) and Cooper et al. (37) also measured increased LDH activity in fish exposed to different pesticides. In addition, Ayanda et al. (38) found significant LDH, as well as ALAT and ASAT in the livers of fish exposed to sublethal concentrations of glyphosate and paraquat, which are two commonly used herbicides. Raj and Joseph (39) consider that the enhanced LDH activity in $O$. mossambicus exposed to acetamiprid in their study may reflect the increased rate of conversion of lactate to pyruvate and then to glucose. Overall, changes in the LDH activity are a maker for tissue damage in fish and a good diagnostic tool in toxicology studies (40). Increase of LDH activity is a diagnostic index widely used to recognize increases of anaerobic metabolism resulting from depletion of energy under anaerobic and environmental stress conditions (33). Thus, we consider that the increased LDH activity caused by the effect of all thiamethoxam concentrations in our study responds to induced oxidative stress in the fish organism, corresponding to a deficiency of ATP and necessity of regeneration of NADH.

Significant changes in ASAT and ALAT activities were observed dependent upon the insecticide concentrations compared to the control group $(p<0.05)$. Similarly to the LDH activity, ASAT and ALAT activities increased with the increasing concentrations of the tested chemical. However, there was no significant difference in ASAT activity between the fish group exposed to $10 \mathrm{mg} \mathrm{l}^{-1}$ and $20 \mathrm{mg} \mathrm{l}^{-1}$ insecticide $(p>0.05)$. In addition, the ALAT activity, which we measured in the fish group exposed to $6.6 \mathrm{mg} \mathrm{l}^{-1}$ and $10 \mathrm{mg} \mathrm{l}^{-1}$ did not differ statistically $(p>0.05)$. The increased ASAT activity at concentration of $6.6 \mathrm{mg} \mathrm{l}^{-1}$ thiamethoxam was higher with $58.5 \%$ (1.59 times), at $10 \mathrm{mg} \mathrm{l}^{-1}$ thiamethoxam $-67.9 \%$ (1.68 times) and at the highest concentration of $20 \mathrm{mg}^{-1}-71.6 \%$ (1.72 times) higher compared to the control group fish, respectively. The values of ALAT activity were as follows: the activity was increased with $190 \%$ (2.9 times) at 6.6 $\mathrm{mg} \mathrm{l}^{-1}$ thiamethoxam, 203.3\% (3.03 times) at $10 \mathrm{mg} \mathrm{l}^{-1}$ and $213.3 \%$ (3.31 times) at the highest concentration of $20 \mathrm{mg} \mathrm{l}^{-1}$ insecticide compared to the control fish group. Thus, any change in the transaminase activity can be correlated with the protein and carbohydrate metabolism and thereby, help in analyzing the metabolic shifts (41). We agree with Philip et al. (42) who state that the elevation in the transaminases indicates the utilization of amino acids for conversion to the keto acids or for glyconeogenesis and is used to determine liver damage. Increased activities of ASAT and ALAT were also observed in Channa punctatus exposed to organophosphorus pesticides (43). Banaee et al. (9) reported increased levels of ASAT and ALAT followed by the exposure of common carp to diazinon. Thus, changes in the activity of aspartate and alanine transaminases affect the energy metabolism in fish.

\section{Histological analysis}

The present study demonstrates that the control fish liver generally exhibited a normal architecture (Fig. 1), which is in agreement with Hibiya (28). However, the

Table 2. Hepatic histological alterations in bighead carp after thiamethoxam exposure.

\begin{tabular}{|c|c|c|c|c|}
\hline \multirow{2}{*}{$\begin{array}{l}\text { Histological } \\
\text { alterations }\end{array}$} & \multicolumn{4}{|c|}{ Thiamethoxam concentration } \\
\hline & $\begin{array}{l}\text { Control } \\
\text { group }\end{array}$ & $\begin{array}{c}6.6 \\
\mathrm{mg} \mathrm{l}^{-1}\end{array}$ & $\begin{array}{c}10 \\
\mathrm{mg} \mathrm{l}^{-1}\end{array}$ & $\begin{array}{c}20 \\
\mathrm{mg} \mathrm{l}^{-1}\end{array}$ \\
\hline Granular degeneration & - & + & ++ & +++ \\
\hline Balloon degeneration & - & $+1-$ & + & ++ \\
\hline Fatty degeneration & - & $+1-$ & $+1-$ & $+1-$ \\
\hline \multirow{3}{*}{\begin{tabular}{|ll} 
Necrotic & Kariorrehiss \\
alterations & Kariopyknosis \\
& Kariolysis
\end{tabular}} & - & - & $+1-$ & $+1-$ \\
\hline & - & $+1-$ & + & ++ \\
\hline & - & $+1-$ & + & ++ \\
\hline Necrosis & - & $+1-$ & $+1-$ & + \\
\hline Lymphocyte proliferation & - & - & $+1-$ & + \\
\hline Hyperemia & - & - & $+1-$ & + \\
\hline
\end{tabular}

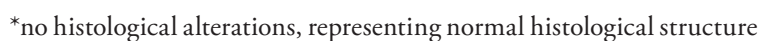
- (-); mild histopathological alterations - 10-20\% - (+/-); moderate histopathological alterations $-30-50 \%-(+)$; severe histopathological alterations $-60-80 \%-(++)$; and very severe histopathological alterations - above $80 \%-(+++)$. 


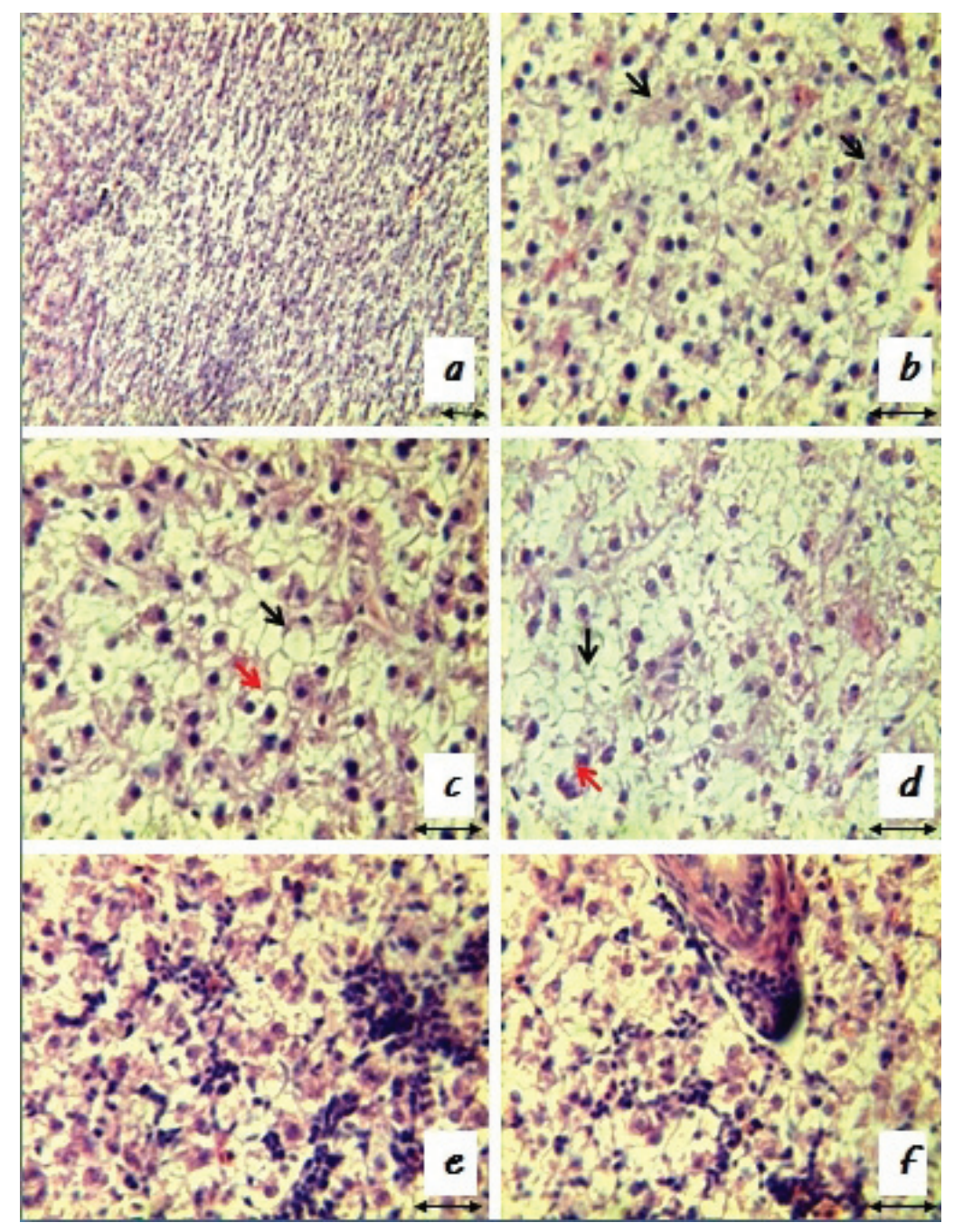

Figure 1. Histological alterations in bighead carp liver, HङE: $\boldsymbol{a}$-normal histological structure, $x 200 ; \boldsymbol{b}$-granular degeneration at concentration of $6.6 \mathrm{mg} \mathrm{l}^{-1}$ thiamethoxam, $x 400 ; \boldsymbol{c}$ - balloon (red arrow) and fatty degeneration (black arrow) at concentration of $10 \mathrm{mg} \mathrm{l}^{-1}$ thiamethoxam, x400; $\boldsymbol{d}$ - necrotic alterations at concentration of $20 \mathrm{mg} \mathrm{l}^{-1}$ thiamethoxam (karyopyknosis - black arrow and karyolysis - red arrow), $x 400 ; \boldsymbol{e}$-lymphocyte proliferation at concentration of $20 \mathrm{mg}^{-1}$ thiamethoxam, $x 400 ; \boldsymbol{f}$-hyperemia at concentration of $20 \mathrm{mg} \mathrm{l}^{-1}$ thiamethoxam, $x 400$.

histological analysis also showed degenerative and necrotic changes in the fish exposed to thiamethoxam, which indicated disturbances in the hepatic blood circulation (Table 2).

We found granular, balloon and fatty degeneration. Furthermore, we determined necrotic alterations in the fish liver, which were presented as karyopyknosis, karyorrehsis and karyolysis. We also found necrotic areas in the liver parenchyma, which were presented in cell mass where the boundaries of the separate hepatocytes could not be established. The histological alterations in the hepatic blood circulatory system were lymphocyte proliferation and hyperemia. The degree of expression of each lesion increased proportionally with the increasing concentrations of thiamethoxam.
At the lowest thiamethoxam concentration $\left(6.6 \mathrm{mgl}^{-1}\right)$ granular degeneration was presented in a moderate degree (Fig. 1b). In addition, we determined balloon and fatty degeneration, as well as necrotic alterations in a mild degree of expression. We did not observed disturbances in the hepatic blood circulation in the fish group exposed to $6.6 \mathrm{mg} \mathrm{l}^{-1}$ thiamethoxam.

Granular degeneration in a severe degree of expression in the fish exposed to $10 \mathrm{mg} \mathrm{l}^{-1}$ thiamethoxam was found. Our results demonstrated that at this concentration balloon degeneration and necrotic alterations were presented in a moderate degree of expression. In addition, fatty degeneration, lymphocyte proliferation and hyperemia were observed in a mild degree. These alterations were shown at a higher level compared to the previous concentration $\left(6.6 \mathrm{mg} \mathrm{l}^{-1}\right)$. Degeneration of hepatocytes was also re- 
ported by Velisek et al. (44) caused by cypermethrin in rainbow trout (Oncorhynchus mykiss).

The histological alterations in the bighead carp liver were most pronounced at the highest tested thiamethoxam concentration $\left(20 \mathrm{mg} \mathrm{l}^{-1}\right)$. We determined granular degeneration in a very severe degree of expression. Balloon degeneration (Fig. 1c), necrotic alterations (Fig. 1d) and changes in the hepatic blood circulatory system (Fig. 1e,f) were in a moderate degree of expression. Fatty degeneration was present in lipid deposits in single hepatocytes of the liver parenchyma (Fig. 1c). Such histological liver changes were also observed in other fish species following pesticides exposure (45-48).

Overall, similarly to other authors (49) our results showed that the histopathological investigations could be used as a sensitive tool to detect direct effects of chemical compounds within target organs of fish in laboratory experiments. In addition, we agree with Boran (50) that fish liver histopathology is an indicator of chemical toxicity and it is a useful way to study the effects of exposure of aquatic animals to toxins present in the aquatic environments.

\section{Histochemical analysis}

In the control group we did not observe a positive reaction to the histochemical staining. On the other hand, in the fish exposed to thiamethoxam we found a positive response (Fig. 2). This indicates the presence of accumulated lipid droplets in the fish hepatocytes from all experimental groups (Table 3).

The results on lipid amount in the fish hepatocytes exposed to thiamethoxam showed a trend to increase the lipid inclusions in the cytoplasm in parallel to the increasing toxicant concentrations. These results were also confirmed by fatty degeneration, which was observed in the histological analysis. Therefore, we consider that the amount of accumulated lipid droplets in the hepatocyte cytoplasm could be due to fatty degeneration.

Similarly to us, Gultekin et al. (51) found hepatic fatty degeneration, which was because of altered lipid metabolism after insecticide exposure. Ayoola (52) also found fatty degeneration in fish hepatocytes after glyphosate exposure for $96 \mathrm{~h}$. In our previous studies (54) in parallel with the increase in the hepatic lipid content we also observed an increase in the glycogen amount. This probably is due to the increased amounts of pyruvate in the liver and hence, the pyruvate dehydrogenase complex increases the acetyl - CoA quantities, which are used for fatty acids and cholesterol synthesis. The increased synthesis of fatty acids also leads to increased synthesis of triglycerides and hyperlipidemia, which on the other hand are associated with fatty infiltration of the hepatocytes. Given the fatty infiltration of the cells, these changes can be linked to the absence of the enzyme glucose-6-phosphatase and
Table 3. Hepatic histochemical alterations in bighead carp after thiamethoxam exposure.

\begin{tabular}{|lcccc|}
\hline $\begin{array}{l}\text { Tiamethoxam } \\
\text { concentration }\end{array}$ & $\begin{array}{c}\text { Control } \\
\text { group }\end{array}$ & $\begin{array}{c}6.6 \\
\mathrm{mg} \mathrm{l}^{-1}\end{array}$ & $\begin{array}{c}10 \\
\mathrm{mg} \mathrm{l}^{-1}\end{array}$ & $\begin{array}{c}20 \\
\mathrm{mg} \mathrm{l}^{-1}\end{array}$ \\
$\begin{array}{l}\text { Intensity of } \\
\text { Sudan III staining }\end{array}$ & - & $+/-$ & $+/-$ & + \\
\hline
\end{tabular}

$(-)$ - negative reaction of histochemical staining; (+/-) - very weak positive reaction of histochemical staining; $(+)$ - weak positive reaction of histochemical staining; $(++)$ - moderate positive reaction of histochemical staining; $(+++)-$ strong positive reaction of histochemical staining in the hepatocytes.
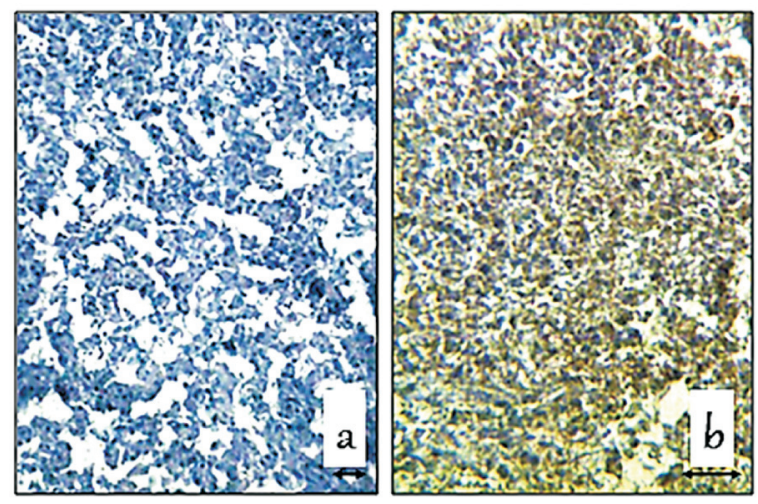

Figure 2. Intensity of Sudan III staining in bighead carp liver: control group (a), $x 200$ and $20 \mathrm{mg} \mathrm{t}^{-1}$ thiamethoxam (b), $x 400$.

inability to release glucose into the blood, leading to hypoglycemia in the fish body. On the other hand, the higher quantities of glucose-6-phosphate lead to enhanced activity of the pentose-phosphate pathway and hence, greater amounts of pyruvate and acetyl - CoA, which is used for the synthesis of fatty acids and cholesterol.

\section{CONCLUSION}

In sum, we could conclude that the studied alterations at different biological level occurred in the hepatic metabolism of the bighead carp organism under the influence of all tested concentrations of thiamethoxam. These changes are probably due to oxidative stress. Moreover, the increase of enzymatic activities is likely to be related, as noted by other authors (55) with enhanced protein catabolism and hepatocellular damage. We also consider that the detected histological and histochemical in the fish liver structure could be a result of changes in the hepatic metabolism under the thiamethoxam influence. Our study shows that there is a relation between the concentration of the insecticide and biochemical changes, as well the severity of expression of the histological alterations in the bighead carp liver. Overall, such experiments could be successfully applied in research and monitoring programs to study the effects of pesticides on fish, and the investigated 
enzymatic and histological changes could be used as sensitive biomarkers for pesticide contamination in field research. Moreover, we also suggest the histochemical alterations as possible biomarkers in ecotoxicological studies.

\section{Acknowledgments}

The authors would like to thank the Ethics Committee for Animals used for Scientific Purposes for approving the experimental design.

\section{REFERENCES}

1. MOGHADAMNIA A A, ABDOLLAHI M 2002 An epidemiological study of poisoning in northern Islamic Republic of Iran, East Mediterr. J Health 8: 88-94

2. ABDOLLAHI M, RANJBAR A, SHADNIA S, NIKFAR S, REIZAIC OF 2004 Insecticides and oxidative stress: A review. Med Sci Monit 10: 141-147

3. MASSARO E J 2002 Handbook of Neurotoxicology, New Jersey, Humana Press Inc http://dx.doi.org/10.1385/1592591655

4. BANAEE M, AHMADI K 2011 Sub-lethal toxicity impacts of endosulfan on some biochemical parameters of the freshwater crayfish (Astacus leptodactylus). Res J Environ Sci 5: 827-835 http://dx.doi.org/10.3923/rjes.2011.827.835

5. DING Y, WESTON D P, YOU J, ROTHERT A K, LYDY M J 2011 Toxicity of sediment associated pesticides to Chironomus dilutes and Hyalella azteca. Arch Environ Contam Toxicol 61: 83-92

6. HOPE B K 2012 Using legacy data to relate biological condition to cumulative aquatic toxicity in the Willamette River Basin (Oregon, USA). Arch Environ Contam Toxicol 62: 424-437 http://dx.doi.org/10.1007/s00244-011-9713-8

7. RAHIMINEZHHAD M, SHAHTAHERI S J, GANJALIM R, RAHIMI FOROUSHANI A, GOLBABAEI F 2009 Moleculary imprinted soild phase extraction for trace analysis of diazinon in drinking water. Iran J Environ Health Sci Eng 6: 97-106

8. ARJMANDI R, TAVAKOL M, SHAYEGHI M 2010 Determination of organophosphorus insecticide residues in the rice paddies. Int J Environ Sci Tech 7: 175-182 http://dx.doi.org/10.1007/BF03326129

9. BANAEE M, MIRVAGHEFI A R, AHMADI K, BANAEE S 2008 Determination of LC50 and investigation of acute toxicity effects of diazinon on hematology and serology indices of common carp (Cyprinus carpio). J Mar Sci Tech Res 3: 1-10

10. BANAEE M, SUREDA A, MIRVAGEFEI A R, AHMADI K 2013 Biochemical and histological changes in the liver tissue of Rainbow trout (Oncorhynchus mykiss) exposed to sub-lethal concentrations of diazinon. Fish Physiol Biochem 39: 489-501

11. MUTHUKUMARAVE K, SATHICK O, RAVEENDRAN $S$ 2013 Lambda cyhalothrin induced biochemical and histological changes in the liver of Oreochromis mossambicus (Peters). Int J Pure Applied Zool 1: 80-85

12. TRIEBSKORN R, KOHLER H R, HONNEN W, SCHRAMM M, ADAMS S M 1997 Induction of heat shock proteins, changes in liver ultra-structure, and alterations of fish behavior: are these biomarkers related and are they useful to reflect the state of pollution in the field. J Aquat Ecosyst Stress Recov 6: 57-73

13. TOPAL A, ATAMANALP M, UÇAR A, ORUÇ E, KOCAMAN EM, SULUKAN E, AKDEMIR F, BEYDEMIR Ş, KILINÇ N, ERDOĞAN O, CEYHUN SB 2015 Effects of glyphosate on juvenile rainbow trout (Oncorhynchus mykiss): Transcriptional and enzymatic analyses of antioxidant defence system, histopathological liver damage and swimming performance. Ecotoxicol Environ Saf 111: 206-214 http://dx.doi.org/10.1016/j.ecoenv.2014.09.027
14. ALMEIDA J A, DINIZ Y S, MARQUES S F G, FAINE A, RIBAS B O, BURNEIKO R C, NOVELLI E I B 2002 The use of the oxidative stress responses as biomarkers in Nile tilapia (Oreochromis niloticus) exposed to in vivo cadmium contamination. Environ Int 27: 673-679

15. CAPKIN E, BIRINCIOGLU S, ALTINOK I 2009 Histopathological changes in rainbow trout (Oncorhynchus mykiss) after exposure to sublethal composite nitrogen fertilizers. Ecotoxicol Environ Saf 72: 1999-2004 http://dx.doi.org/10.1016/j.ecoenv.2009.05.007

16. JIRAUNGKOORSKUL W, UPATHAM ES, KRUATRACHUE M, SAHAPHONG S, VICHASRI-GRAMS S, POKETHITIYOOK P 2003 Biochemical and histopathological effects of glyphosate herbicide on Nile tilapia (Oreochromis niloticus). Environ Toxicol, 18: 260-267 http://dx.doi.org/10.1002/tox.10123

17. THOPHON S, KRUATRACHUE M, UPATHAM ES, POKETHITIYOOK P, SAHAPHONG S, JARITKHUAN S 2003 Histopathological alterations of white seabass, Lates calcalifer, in acute and subchronic cadmium exposure. Environ Pollut 121: 307-320 http://dx.doi.org/10.1016/S0269-7491(02)00270-1

18. HINTON D E, LAUREN D J 1990 Liver structural alterations accompanying chronic toxicity in fishes: potential biomarkers of exposure. In: Biomarkers of Environmental Contamination, McCarthy JF, Shugart LR (eds.). Lewis Publishers. Boca Raton.

19. BIAGIANTI-RISBOURG S 1997 Les perturbations (ultra) structurales du foie des poissons utilisés comme biomarqueurs de la qualité sanitaire des milieux aquatiques. In: Utilisation de Biomarqueurs en Ecotoxicologie, Aspects Fondamentaux, Lagadic L, Caquet T, Amiard JC, Ramade F (eds.). Masson Pub. Paris.

20. FISHEL F M 2005 Pesticide toxicity profile: Neonicotinoid Pesticides, available at http://edis.ifas.ufl.edu/PI117

21. APHA 2005 Standard methods for examination of water and wastewater, $21^{\text {st }}$ ed., American Public Health Association. Washington, DC.

22. ROSSELAND B O, MASSABUAU J C, GRIMALT J, HOFER R, LACKNER R, RADDUM G, RADDUM G, ROGNERUD S, VIVES I 2003 Fish ecotoxicology: European mountain lake ecosystems regionalisation, diagnostic and socio-economic evaluation (EMERGE), Fish sampling manual for live fish, Norwegian Institute for Water Research (NIVA). Oslo. Norway.

23. DIRECTIVE 2010/63/EU of the European Parliament and of the Council on the protection of animals used for scientific purposes. Official Journal of the European Union

24. VASSAULT A 1983 Lactate dehydrogenase. In: Methods of Enzymatic Analysis, Enzymes: Oxireductases, Transferases, Bergmeyer MO (ed.). Academic Press. New York.

25. REITMAN S, FRANKEL S 1957 A colorimetric method for the determination of serum glutamic oxaloacetic and glutamic pyruvic transaminases. Am J Clin Pathol 28: 56-63

26. IFCC (International Federation of Clinical Chemistry) 1986 Methods for the measurement of catalytic concentration of enzymes, Part 2, IFCC method for aspartate aminotransferase (L-aspartate: 2-oxogluarate aminotransferase, EC 2.6.1.1). J Clin Chem Clin Biochem 24: 497-510

27. BRADFORD M 1976 A rapid and sensitive method for the quantitation of microgram quantities of protein using the principle of protein dye binding. Analyt Biochem 72: 248-254 http://dx.doi.org/10.1016/0003-2697(76)90527-3

28. TAKASHIMA F, HIBIYA T, 1995 An atlas of fish histology: Normal and Pathological features, $2^{\text {nd }}$ ed., Kodansha Ltd. Tokyo

29. MISHRA A K, MOHANTY B 2008 Acute toxicity impacts of hexavalent chromiumon behavior and histopathology of gill, kidney and liver of the freshwater fish, Channa punctatus (Bloch). Environ Toxicol Pharmacol 26: 136-141

30. Daddi L 1896 Nouvelle méthode pour colorer la graisse dans les tissues. Arch Ital Biol f26: 143-146 
31. PEARSE A G E 1972 Histochemistry: Theoretical and Applied, 3rd ed., London, Churchill-Livingstone

32. AHMAD R, Hasnain A 2005 Ontogenetic changes and developmental adjustments in lactate dehydrogenase isoezymes of an obligate air-breathing fish Channa punctatus during deprivation of air access. Comp Biochem Physiol 140: 271-278 http://dx.doi.org/10.1016/j.cbpc.2004.10.012

33. BANAEE M 2013 Physiological dysfunction in fish after insecticides exposure. In: Insecticides - Development of Safer and More Effective Technologies, Trdan S. (ed.). In Tech. Croatia, p. 558 http://dx.doi.org/10.5772/54742

34. BALINT T, FERENCZY J, KATAI F 1997 Similarities and differences between the massive eel (Anguilla anguilla L.) devastations that occurred in lake Balaton in 1991 and 1995. Ecotox Environ Saf 37: 17-23 http://dx.doi.org/10.1006/eesa.1996.1509

35. DAS K B, MUKHERJEE C S 2003 Toxicity of cypermethrin in Labeo rohita fingerlings: biochemical, enzymatic and haematological consequences. Comp Biochem Phys 134: 109-121 http://dx.doi.org/10.1016/s1532-0456(02)00219-3

36. Oruç Ö E, ÜNER N 1998 Effects of azinphosmethyl on some biochemical parameters in blood, muscle, and liver tissues of Cyprinus carpio (L.). Pestic Biochem Phys 62: 65-71

37. COOPER R U, CLOUGH L M, FARWELL M A, WEST T L 2002 Hypoxia-induced metabolic and antioxidant enzymatic activities in the estuarine fish Leiostomus xanthurus. J Exp Mar Biol Ecol 279: 1-20 http://dx.doi.org/10.1016/S0022-0981(02)00329-5

38. AYANDA O I, ONIYE S J, AUTA J A, AJIBOLA V O, BELLO O A 2015 Responses of the African catfish Clarias gariepinus to long-term exposure to glyphosate and paraquat-based herbicides. Afr J Aquat Sci 40: 261-267 http://dx.doi.org/10.2989/16085914.2015.1074882

39. RAJ S J, JOSEPH B 2015 Impact of acetamiprid toxicity on lactate dehydrogenase in some tissues of the fish Oreochromis mossambicus. Int J Zool Res 11: 112-115

40. MIN E Y, KANG J C 2008 Effect of waterborne benomyl on the hematological and antioxidant parameters of the Nile tilapia, Oreochromis niloticus. Pest Biochem Physiol 92: 138-143 http://dx.doi.org/10.1016/j.pestbp.2008.07.007

41. BEYER J, SANDVIK M, HYLLAND K, FJELD E, EGAAS E, AAS E, SKARE J U 1996 Contaminant accumulation and biomarker responses in flounder (Platichthys Xesus L.) and atlantic cod (Cadus morhua L.) exposed by caging to polluted sediments in Sorforden, Norway. Aquat Toxicol 36: 75-98 http://dx.doi.org/10.1016/S0166-445X(96)00798-9

42. PHILIP G H, REDDY P M, SRIDEVI G 1995 Cypermethrin induced in vivo alterations in the carbohydrate metabolism of freshwater fish Labeo rohita. Ecotoxicol Environ Saf 31: 173-178
43. AGRAHARI S, PANDEY K C, GOPAL K 2007 Biochemical alteration induced by monocrotophos in the blood plasma of fish, Channa punctatus (Bloch). Pestic Biochem Phys 88: 268-272.

44. VELISEK J, WLASOW T, GOMULKA P, SVOBODOVA Z, DOBSIKOVA R, NOVOTNY L, DUDZIK M 2006 Effects of cypermethrin on rainbow trout (Oncorhynchus mykiss). Vet Med 51: 469-476

45. TILAK K S, VEERAIAH K, SUSAN T A, YACOBU K 2001 Toxicity and residue studies of fenvalerate to some selected freshwater fishes. J Environ Biol 22: 177-180

46. SARKAR B, CHATTERJEE A, ADHIKARI S, AYYAPPAN $S$ 2005 Carbofuran and cypermethrin-induced histopathological alterations in the liver of Labeo rohita (Hamilton) and its recovery. J Appl Ichthyol 21: 131-135 http://dx.doi.org/10.1111/j.1439-0426.2004.00590.x

47. VELMURUGAN B, SELVANAYAGAM M, CENGIZ E I, UNLU E 2007a Histopathology of lambda-cyhalothrin on tissues (gill, kidney, liver and intestine) of Cirrhinus mrigala. Environ Toxicol Pharmacol 24: 286-291

48. VELMURUGAN B, SELVANAYAGAM M, CENGIZ E I, UNLU E 2007b The effects of fenvalerateon different tissues of freshwater fish Cirrhinus mrigala. J Environ Sci Health 42: 157-163

49. SCHWAIGER J, FENT K, STECHER H, FERLING H, NEGELE R D 1996 Effects of sublethal concentrations of triphenyltinacetate on raibow trout (Oncorhynchus mykiss). Arch Environ Contam Toxicol 30: 327-334 http://dx.doi.org/10.1007/BF00212290

50. BORAN H, ALTINOK I, CAPKIN E 2010 Histopathological changes induced by maneb and carbaryl on some tissues of rainbow trout, Oncorhynchus mykiss. Tissue and Cell 42: 158-164 http://dx.doi.org/10.1016/j.tice.2010.03.004

51. GULTEKIN F, OZTURK M, AKDOGAN M 2000 The effect of organophosphate insecticide chlorpyrifosethyl on lipid peroxidation and antioxidant enzymes (in vitro). Arch Toxicol 74: 533-538 http://dx.doi.org/10.1007/s002040000167

52. AYOOLA SO. 2008 Toxicity of glyphosate herbicide on Nile tilapia (Oreochromis niloticus) juvenile. Afr J Agric Res 3: 825-834

53. STOYANOVA S, YANCHEVA V, VELCHEVA I, ATANASOVA P, GEORGIEVA E 18452015 Thiamethoxam causes histochemical changes in the liver of Aristichthys nobilis Rich., 1845. J BioSci Biotech 4(3): 321-325

54. SHARMA B 1999 Effect of carbaryl on some biochemical constituents of the blood and liver of C. batrachus, a fresh water teleost. J Toxicol Sci 24: 157-164 http://dx.doi.org/10.2131/jts.24.3_157 